Mathematic Education And Aplication

Volume 03, No. 2, Desember 2021, pp. 33-38

\title{
IDENTIFIKASI MINAT BELAJAR MATEMATIKA SISWA SMP MUHAMMADIYAH 1 TARAKAN DALAM PEMBELAJARAN DARING DI MASA PANDEMI COVID-19
}

\author{
Setia Widia Rahayu ${ }^{1}$ \\ ${ }^{1}$ Pendidikan Matematika, Universitas Borneo Tarakan \\ ${ }^{1}$ Setiayura09@gmail.com
}

\begin{abstract}
The learning process underwent a surprising change, due to the Covid-19 pandemic. The Minister of Education makes a decision to implement online learning. Because learning is carried out online, teachers and students must continue to adjust learning which is usually face-to-face, this is only through virtual. Researchers conducted observations at SMP Muhammadiyah 1 Tarakan, obtained information that in the implementation of online learning, students were often late for zooming, and sometimes students did not attend learning activities via zoom. Assignments given by the teacher are often late for students to collect. In addition to observations, interviews with mathematics teachers were also conducted, he provided information that the low enthusiasm of students to learn online, students' readiness to learn seemed to be lower than in direct learning. From the problems that appear in the field, the author is interested in conducting a research entitled "Identification of Student Interests in SMP Muhammadiyah 1 Tarakan in Online Learning in the Covid-19 Pandemic Period". The type of research used in this research is quantitative research. Based on the results of the research carried out, it was concluded that the interest in learning of SMP Muhammadiyah 1 Tarakan students during Study From Home (BDR) during the COVID-19 Pandemic was in the medium category at $61 \%$, in the high category at $17 \%$ and in the low category at $22 \%$.
\end{abstract}

Keywords : Interest in Learning, Mathematics, Online Learning

\begin{abstract}
Abstrak
Proses pembelajaran mengalami perubahan yang cukup mengejutkan, dikarenakan kondisi Pandemi Covid19. Menteri Pendidikan mengambil keputusan untuk dilaksanakannya pembelajaran secara Daring. Karena pembelajaran dilaksanakan secara Daring, maka Guru dan siswa harus tetap menyesuaikan pembelajaran yang biasanya secara tatap muka, ini hanya melalui virtual. Peneliti melaksanakan observasi di SMP Muhammadiyah 1 Tarakan, diperoleh informasi bahwa dalam pelaksanaan pembelajaran daring, siswa sering terlambat mengikuti zoom, bahkan tak jarang siswa tidak hadir dikegiatan pembelajaran melalui zoom. Tugas yang diberikan guru sering terlambat dikumpulkan oleh siswa. Selain observasi, dilakukan juga wawancara dengan guru matematika, beliau memberikan informasi bahwa rendahnya antusiasme belajar siswa secara daring, kesiapan belajar siswa terlihat lebih menurun dibandingkan pembelajaran secara langsung. Dari permasalahn yang tampak dilapangan maka penulis tertarik untuk melakukan penelitian yang berjudul "Identifikasi Minat Belajar Siswa SMP Muhammadiyah 1 Tarakan Dalam Pembelajaran Daring di Masa Pandemi Covid-19". Jenis penelitian yang digunakan dalam penelitian ini adalah penelitian kuantitatif. Berdasarkan hasil penelitian yang dilaksanakan diperoleh kesimpulan bahwa minat belajar siswa SMP Muhammadiyah 1 Tarakan selama Belajar Dari Rumah (BDR) di masa Pandemi COVID-19 berada pada kategori sedang yaitu sebesar 61\%, kategori tinggi sebesar $17 \%$ dan kategori rendah $22 \%$.
\end{abstract}

Kata kunci: Minat Belajar, Matematika, Pembelajaran Daring

Cara Menulis Sitasi: Rahayu, S. W., (2021). Identifikasi Minat Belajar Matematika Siswa SMP Muhammadiyah 1 Tarakan Dalam Pembelajaran Daring di Masa Pandemi Covid-19. Mathematic Education and Aplication Journal, volume 03 no.2, halaman 35-40

Pendidikan di Indonesia dewasa ini semakin berkembang menuju arah yang lebih baik. Pendidikan bertujuan untuk mengembangkan kemampuan seorang atau kelompok sehingga bermanfaat bagi diri sendiri maupun orang lain. Agar tujuan pendidikan dapat tercapai, maka perlu 
dilakukan usaha secara sadar dan terencana yang dilaksanakan pada semua jenis pendidikan yang ada.

Didalam dunia Pendidikan tidak akan pernah terpisahkan dengan proses belajar. Proses belajar itu sendiri adalah memanusiakan manusia dimana hanya melalui belajarlah manusia menemukan dirinya dalam hubungannya dengan sesama, lingkungan dan pencipta. Melalui belajar, manusia mengaktualisasikan diri dan lingkungannya sehingga kualitas hidup dan kehidupan menjadi lebih baik. Belajar dapat dilakukan dimana saja, kapan saja dan oleh siapa saja. Dalam situasi formal, belajar tidak dapat dipisahkan dari pembelajaran. Belajar merupakan akibat dari tindakan pembelajaran (Slameto, 2005:5). Secara sederhana, istilah pembelajaran bermakna sebagai upaya untuk membelajarkan seseorang atau kelompok orang melalui berbagai strategi, metode dan pendekatan kearah pencapaian tujuan yang telah direncanakan. Pembelajaran dapat pula dipandang sebagai kegiatan guru secara terprogram dalam desain intruksional untuk membuat siswa belajar secara aktif.

Pada awal Maret 2020, proses pembelajaran mengalami perubahan yang cukup mengejutkan, dikarenakan kondisi Pandemi Covid-19. Menteri Pendidikan mengambil keputusan untuk dilaksanakannya pembelajaran secara Daring. Kondisi pembatasan kegiatan ini sebagai upaya memutus rantai penyebaran Covid-19. Karena pembelajaran dilaksanakan secara Daring, maka Guru dan siswa harus tetap menyesuaikan pembelajaran yang biasanya secara tatap muka, ini hanya melalui virtual. Kondisi ini menuntut guru untuk dapat menciptakan suasana belajar semenarik mungkin. Siswa juga harus memiliki kesiapan dan kemandirian belajar yang tinggi, agar tujuan pembelajaran tetap tercapai.

Peneliti melaksanakan observasi di SMP Muhammadiyah 1 Tarakan pada bulan Oktober 2021, diperoleh informasi bahwa dalam pelaksanaan pembelajaran daring, siswa sering terlambat mengikuti zoom, bahkan tak jarang siswa tidak hadir dikegiatan pembelajaran melalui zoom. Tugas yang diberikan guru sering terlambat dikumpulkan oleh siswa. Untuk menambah informasi, dilakukan juga wawancara dengan guru matematika SMP Muhammadiyah 1 Tarakan, beliau memberikan informasi bahwa rendahnya antusiasme belajar siswa secara daring, kesiapan belajar siswa terlihat lebih menurun dibandingkan pembelajaran secara langsung. Selain itu, tampak juga ketika sedang berlangsung pembelajaran melalui zoom terdapat siswa yang telalu tegang dalam pembelajaran matematika, sulitnya pembelajaran melalui zoom yang mengharuskan memperaktekkan penjawabaran dalam bidang rumus-rumus matematika, dan adapun sulitnya mengerjakan tugas-tugas yang diberikan oleh guru ketika pembelajaran matematika sedang berlangsung Masalah lain yang dialami siswa dalam pembelajaran matematika yang dapat dilihat adalah dalam proses pembelajaran matematika melalui zoom, banyak siswa yang tidak dipantau belajarnya dari rumah oleh orang tuanya sendiri yang membuat siswa jadi malas memperhatikan apa 
yang telah di sampaikan oleh guru namun ada beberapa siswa yang masih dipantau orang tuanya bahkan ikut kedalam zoom pembelajaran matematika dan permasalahan yang lain yang lebih menonjol adalah guru sering mengingatkan tentang tugas yang akan dikumpul, namun banyak siswa yang masih acuh - tak acuh akan tugas yang diberikan oleh guru yang membuat guru hanya bisa mengingatkan dengan bahasa lembut kepada siswanya. Hal ini dikarenakan sebelumnya adanya kasus bunuh diri siswa yang terjadi dikota lain yang berdampak dalam proses pembelajaran.

Slameto dalam Asmani (2009: 32) mengatakan bahwa Minat adalah rasa lebih suka dan ketertarikan pada suatu hal atau aktivitas tertentu, tanpa ada yang menyuruh. Demikian di dalam diri seseorang, dimana dia mulai tertarik akan sesuatu khususnya dalam pembelajaran dikarenakan seseorang menaruh minat terhadap hal tersebut. Minat adalah ketertarikan seseorang akan sesuatu yang timbul dari dalam diri, Minat dapat membangkitkan motivasi dan berpengaruh terhadap hasil dan prestasi belajar. Menurut Baharudin, minat adalah kecenderungan dan kegairahan yang tinggi atau keinginan yang besar terhadap sesuatu (Baharudin 2008: 24). Sedangkan Slameto berpendapat bahwa minat pada dasarnya adalah penerimaan akan suatu hubungan antara diri sendiri dengan sesuatu diluar diri. Semakin kuat hubungan tersebut, semakin kuat minat (Slameto, 2003: 57). Minat dapat membangkitkan motivasi pada diri seseorang. Timbulnya minat pada diri seseorang karena adanya ketertarikan dan perhatian pada satu objek atau pelajaran tertentu disertai dengan perasaan senang, sehingga bila siswa tertarik pada sesuatu maka ia berusaha (termotivasi) untuk melakukan sesuatu yang diminatinya, sebaliknya tanpa minat seseorang tidak mungkin melakukan sesuatu. Melalui adanya minat, maka siswa berusaha untuk mengetahui suatu pelajaran dengan cara mengetahui, mengikuti, dan memahami pelajaran.

Minat dapat memengaruhi kualitas pencapaian hasil belajar siswa dalam bidang studi tertentu, umpamanya seorang siswa yang menaruh minat besar terhadap suatu mata pelajaran matematika, maka ia akan memusatkan perhatiannya lebih banyak daripada siswa lain. Kemudian, karena pemusatan perhatian yang intensif terhadap materi itulah yang memungkinkan siswa tadi untuk belajar lebih giat, dan akhirya mencapai prestasi yang diinginkan. Minat memiliki hubungan yang sangat erat dengan kepribadian seseorang. Dengan tumbuhnya minat dalam diri seseorang akan melahirkan perhatian untuk melakukan sesuatu dengan tekun dalam jangka waktu yang lama, lebih berkonsentrasi, mudah untuk mengingat dan tidak mudah bosan dengan apa yang dipelajari. Kegiatan belajar mengajar dapat berjalan dengan baik apabila siswa memiliki minat belajar yang besar. Siswa yang tidak memiliki minat belajar akan merasa malas dan tidak semangat dalam mengikuti pembelajaran. Minat belajar merupakan keseluruhan daya penggerak psikis dalam diri siswa yang menimbulkan belajar. Siswa yang mengikuti pelajaran karena minat sendiri bukan karena paksaan atau ikut-ikutan tentunya prestasinya akan berbeda. Siswa yang memiliki minat belajar tentunya akan mampu menyelesaikan masalah matematika yang dihadapi. Melalui minat belajar yang tinggi 
diharapkan siswa dapat memperoleh hasil belajar yang tinggi pula.Karena dengan minat siswa dapat lebih perhatian tehadap pelajaran, lebih berkonsentrasi, pelajaran lebih mudah melekat dan tidak cepat bosan saat belajar (dalam Diana, 2017: 24).

Sedangkan menurut Sabri (2002: 85) minat dalam belajar memiliki fungsi sebagai berikut:

a. Sebagai kekuatan yang akan mendorong siswa untuk belajar. Siswa yang berminat kepada pelajaran akan tampak terdorong terus untuk tekun belajar.

b. Pendorong siswa untuk berbuat dalam mencapai tujuan.

c. Penentu arah perbuatan siswa yakni ke arah tujuan yang hendak dicapai.

d. Penseleksi perbuatan sehingga perbuatan siswa yang mempunyai motivasi senantiasa selektif dan tetap terarah kepada tujuan yang ingin dicapai

Menurut Rahayu (2019: 26) masalah matematika adalah suatu soal yang harus dipecahkan oleh seseorang (termasuk siswa), namun penyelesaiannya tidak dapat dilakukan secara rutin dan tidak langsung ditemukan penyelesaiannya. Masalah matematika dalam matematika sekolah disajikan secara khas dalam bentuk verbal, gambar, atau simbol matematika atau kombinasi dari ketiganya.

Berdasarkan uraian di atas, maka penulis tertarik untuk melakukan penelitian yang berjudul "Identifikasi Minat Belajar Siswa SMP Muhammadiyah 1 Tarakan Dalam Pembelajaran Daring di Masa Pandemi Covid-19". Tujuan dari penelitian ini adalah untuk melihat minat belajar matematika d siswa SMP Muhammadiyah 1 Tarakan dalam pembelajaran daring dimasa pandemi covid-19.

\section{METODE}

Jenis penelitian yang digunakan dalam penelitian ini adalah penelitian kuantitatif. Menurut Sugiyono (2016:14) penelitian kuantitatif adalah metode penelitian yang berlandaskan pada filsafat positivism, digunakan untuk meneliti pada populasi atau sampel tertentu, pengumpulan data menggunakan instrumen penelitian, analisis data bersifat statistik, dengan tujuan untuk menguji hipotesis yang telah ditetapkan. Penelitian ini dilaksanakan di SMP Muhammadiyah 1. Adapun populasi yang digunakan dalam penelitian ini adalah seluruh siswa SMP Muhammadiyah 1 Tarakan, yang berjumlah 36 siswa.

\section{HASIL DAN PEMBAHASAN}

Untuk melihat kategori minat belajar maka dilakukan distribusi kategori variabel. Tingkat kategori minat belajar dibagi menjadi 5, yaitu sangat tinggi, tinggi, sedang, rendah dan sangat 
rendah. Data hasil distribusi kategorisasi minat belajar dan hasil perhitungan dari tiap indikator secara lengkap dapat dilihat pada tabel berikut:

Tabel 1. Kategorisasi Minat Belajar

\begin{tabular}{|c|c|c|c|}
\hline Interval & Kategori & Frekuensiuensi & Persentase (\%) \\
\hline $78<\mathrm{X}$ & Sangat Tinggi & 0 & 0 \\
\hline $66<\mathrm{X} \leq 78$ & Tinggi & 6 & $17 \%$ \\
\hline $54<\mathrm{X} \leq 66$ & Sedang & 22 & $61 \%$ \\
\hline $42<\mathrm{X} \leq 54$ & Rendah & 8 & $22 \%$ \\
\hline $\mathrm{X} \leq 42$ & Sangat Rendah & 0 & 0 \\
\hline Jumlah & & 36 & 100 \\
\hline
\end{tabular}

Berdasarkan tabel diatas dapat diketahui bahwa Minat belajar siswa SMP Muhammadiyah 1 Tarakan selama BDR masa Pandemi COVID-19 berada pada kategori sedang yaitu sebesar $61 \%$ atau sebanyak 22 siswa dan kategori tinggi sebesar 17\%, sedangkan kategori rendah sebesar $22 \%$.

Hasil dari penyebaran angket minat belajar kepada 36 responden siswa SMP Muhammadiyah 1 Tarakan yang menjadi sampel penelitian. Diperoleh data yang kemudian dilakukan analisis. Analisis dilakukan melalui analisis statistika deskriptif dan analisis statistika inferensial.

Berdasarkan analisis statistik deskriptif minat belajar siswa SMP Muhammadiyah 1 Tarakan dapat diketahui bahwa siswa yang memiliki minat belajar yang dominan pada kategori sedang yaitu sebesar $61 \%$ atau sebanyak 22 siswa dari jumlah sampel 36 responden. Dari data tersebut dapat dikatakan bahwa dari setiap indikator minat belajar, siswa paling sulit dalam hal kegiatan pembelajaran di rumah. Hal ini disebabkan karena siswa masih merasa bahwa keinginan untuk belajar dirumah akan terjadi jika disuruh orang tuanya atau diawasi selama pembelajaran daring berlangsung. Namun pada kenyataannya orang tua masih tidak dapat mengawasi sepenuhnya pembelajaran daring yang berlangsung di rumah. Hasil analisis ini pada dasarnya siswa kurang memiliki minat belajar dalam dirinya, minat belajar tersebut berkaitan dengan ketertarikan siswa yang timbul di dalam diri sendiri.

\section{KESIMPULAN}

Berdasarkan hasil penelitian yang dilaksanakan diperoleh kesimpulan bahwa minat belajar siswa SMP Muhammadiyah 1 Tarakan selama Belajar Dari Rumah (BDR) di masa Pandemi COVID19 berada pada kategori sedang yaitu sebesar 61\%, kategori tinggi sebesar 17\% dan kategori rendah $22 \%$. 


\section{DAFTAR PUSTAKA}

Agung DP. 2005. Pengaruh minat terhadap hasil belajar matematika siswa SMA Negeri 1 Uluiwoi Kabupaten Kolaka Timur. Jurnal penelitian pendidikan matematika. 3(2): 18-19

Ahmadi. 2010. Proses pembelajaran Kreatif Dan Inovatif Dalam Kelas. Jakarta: PT Prestasi Pustakarya.

Asmani, Jamal, MM. 2009. Jurus-jurus Belajar Efektif untuk SMP dan SMA. Yogyakarta: DIVA Press.

Kurniawan, dkk. 2016. Metode penelitian kuantitatif. Yogyakarta. Pandira

Siregar, Syofian. 2014. Statistik Parametrik untuk Peneltian Kuantitatif.

Slameto. 2005. Belajar dan Faktor yang Mempengaruhinya. Edisi Revisi. Jakarta: Rineka Cipta.

Sugiyono. 2016. Metode Penelitian Pendidikan (Pendekatan Kuantitatif, Kualitatif, dan R\&D). Bandung. Alfabeta.

Rahayu, Setia Widia. 2019. Pemahaman Siswa SMP dalam Memecahkan Masalah Aljabar Ditinjau dari Kecerdasan Spasial Sedang. Jurnal Borneo Saintek, 2 (2), pp. 25-30 